\title{
O PASSADO NAS OBRAS DE ZÉLIA GATTAI A PARTIR DE SUA ESCRITURA MEMORIALISTA
}

\author{
KASSIANA BRAGA \\ Universidade Estadual Paulista "Júlio de Mesquita Filho" \\ (UNESP/Assis-SP)
}

\section{RESUMO}

Este texto trata do memorialismo nas obras da escritora Zélia Gattai, a partir de sua primeira publicação no final da década de 1970, enfatizando a maneira como a escritora teceu as suas narrativas e como se apropriou do passado, construindo suas histórias pessoais e de pessoas com quem conviveu ao longo de sua vida. O intuito é perceber as particularidades de sua escrita autobiográfica, centrada em si, e biográfica, voltada para a construção de memórias "alheias", levando em conta o legado que objetivava deixar à posterioridade a partir de seu hibridismo literário.

PALAVRAS-CHAVE: Passado; Memória; Autobiografia; Biografia; Hibridismo Literário.

\section{ABSTRACT}

This text discusses the memorialism in the books of writer Zélia Gattai from her first publication at the 70's, focusing on the way she wrote his narrative and how appropriated the past, building their personal and the other people stories who had contact throughout his life. The proposal is to understand the particularities of his autobiographical writing, when selfcentered, and the biographical toward the construction of memories of others, including the legacy we want to leave for posterity whith his literary hybridity.

KEYWORDS: $\quad$ Past; $\quad$ Memory; Autobiography; Biography; Literary Hybridity. 


\section{Considerações sobre a autora e o boom autobiográfico}

Falar sobre Zélia Gattai no Brasil é lembrar que, antes de ser reconhecida como escritora, a sua imagem como esposa e companheira inseparável do importante escritor baiano Jorge Amado é ainda o mais valorizado, o que não deve desmerecer o seu histórico profissional, capacidade e talento próprios. No entanto, assim como seu Amado, ela também construiu ao longo de anos uma carreira literária que se expressa na publicação de $14 \operatorname{livros}^{1}$ e, assim, o reconhecimento por parte de seus pares no campo das letras e a sua entrada na Academia Brasileira de Letras, a ABL, no ano de 2001, tomando posse em 2002. Trata-se de uma "tri acadêmica", porque também conquistou outras vagas em mais duas academias, como a Academia de Letras da Bahia e a de Ilhéus, no mesmo ano.

Sendo a grande companheira, desde a década de 1940, e "braço direito" de Jorge Amado, Zélia Gattai começou a adentrar o "mundo literário" a partir do momento em que estabeleceu um relacionamento com o escritor, depois que se separou do seu primeiro esposo Aldo Veiga, membro do PCB (Partido Comunista Brasileiro) com quem teve o primeiro filho. A cumplicidade não era apenas no sentido pessoal: havia uma união e ajuda profissionais; era ela quem cuidava dos afazeres domésticos e também quem datilografava e revisava as obras de Amado, desde a publicação de Seara Vermelha (1946).

Zélia auxiliava 0 marido nas escolhas de nomes para alguns personagens, acompanhando-o em seus diversos compromissos, nos congressos, nas atividades do Movimento Comunista Internacional e até mesmo no exílio na Europa, no período de 1948 a 1952, conhecendo inúmeros países como a China, a Itália, a Alemanha, Portugal, Rússia, Mongólia, entre outros, morando posteriormente na França e na Tchecoslováquia. Tal viagem foi de grande riqueza cultural para ambos e, apesar de estarem em exílio, a "viagem de fuga" por conta do medo do escritor ser preso mais uma vez, como membro do PCB e ex-deputado federal pelo mesmo partido que no momento encontrava-se na ilegalidade, seria a única alternativa naquele momento; refugiar-se em país estrangeiro era uma maneira de não perder a liberdade e uma forma de continuar a sua militância política e a publicar suas obras nos países que compactuavam com os seus ideais.

O exílio não se tornou um fardo para o casal, pois o quanto puderam aproveitaram as viagens, os encontros com escritores de outros lugares, intelectuais, poetas e poetisas, pintores e filósofos com os quais acabaram se deparando. Nesses países em que residiram construíram um verdadeiro lar

\footnotetext{
${ }^{1}$ A memorialista escreveu 14 livros, de modo que a maioria de sua obra é composta por autobiografias; contudo, debruçou-se a escrever também livros infantis e um romance. São suas as obras: Anarquistas graças a Deus (1979), Um chapéu para viagem (1982), Pássaros noturnos do Abaeté (1983), Senhora dona do baile (1984), Jardim de inverno (1988), Pipistrelo das mil cores (1989). Literatura infantil: O segredo da rua 18 (1991), Chão de meninos (1992), Crônica de uma namorada (1995), Códigos de família (2001). Romance: A casa do Rio Vermelho (1999), Città di Roma (2000), Joana e a sereia (2000), Jorge Amado: um baiano romântico e sensual (2002), Memorial do amor (2004) e a última publicação Vacina de sapo e outras lembranças (2006).
} 
aconchegante, sempre cercado de amigos que também estavam na Europa por conta do exílio ou de eventos políticos, como algumas reuniões e congressos. Neste sentido, Jorge e Zélia sempre recebiam ilustres visitas ou mesmo encontravam amigos e conhecidos nos eventos que frequentavam em suas viagens, como o poeta Pablo Neruda, a poetisa Antonieta Dias de Moraes, João Cabral, Nicolás Guillén, a filósofa Anna Seghers, entre muitos outros intelectuais vinculados ao Partido Comunista ou mesmo sem vínculo partidário, mas engajados em causas humanitárias contra guerras e conflitos políticos que ocorriam neste período, como a Guerra Fria e o temor da bomba atômica, 0 grande pavor de todos os países naquele momento.

Além de aproveitar os atrativos culturais e recreativos que o exílio lhe proporcionava, Zélia matriculou-se em um curso de Língua e Civilização Francesa na Sorbonne que frequentou durante um ano, de 1948 a 1949, demonstrando que soube aproveitar todas as oportunidades que teve durante a sua vida, antes e depois de se tornar uma escritora conhecida.

Tais vivências possibilitadas pelo contato com culturas distintas, com diversos intelectuais e a experiência adquirida a partir das revisões dos livros de seu esposo, é que fizeram com que Zélia Gattai, de forma gradativa, tomasse gosto pela escritura literária. No entanto, escreveu de modo distinto de Jorge, debruçando-se a contar histórias a partir de suas lembranças de infância e fase adulta, algumas próprias de sua memória e outras adquiridas a partir das narrativas de seus antepassados, que as acaba relatando em muitas de suas obras. Diferente de Jorge Amado que foi um romancista por excelência, a escritora debruçou-se a criar autobiografias, que compõem a maioria de suas obras, no entanto, também produziu romances e livros infantis durante muitos anos.

A sua primeira publicação literária, intitulada Anarquistas, graças a Deus, publicada no ano de 1979 aos 63 anos de idade, conta com imensa bagagem de experiência de vida, recordações e sentimentos guardados que conseguiu exteriorizar a partir de sua literatura em um contexto de abertura política, mas ainda inserido no regime militar brasileiro. À época, este livro fora bem visto pelos críticos e pelos leitores de uma forma geral, logrando a Zélia vários prêmios durante e depois de sua consagração como escritora. Neste momento, assim como Zélia, muitos outros autores e autoras publicaram livros de gêneros literários distintos, como romances, biografias, autobiografias e contos, construindo suas histórias, relatando seus pensamentos, sentimentos e anseios.

A produção literária de Zélia Gattai, bem como o seu pensamento, inserem-se no contexto do aumento do número de publicações literárias ocorrido na década de 1970, sobretudo em relação aos gêneros autobiográficos, dado em função de vários fatores, dentre eles, o da necessidade de certos militantes de esquerda, de escritores/as, de políticos e de jornalistas relatarem o que vinham vivenciando durante o regime militar.

Além do gênero autobiográfico, a obra de Zélia Gattai associa-se ao gênero dos romances políticos que foram, neste período da vida política brasileira, os mais vendidos. Neste "cenário literário" apareceram, ainda, vários 
escritores que se debruçaram sobre este tipo de escrita mais politizada como, por exemplo, Érico Veríssimo e Chico Buarque de Holanda. Outro tipo literário bastante vendido na época foi o dos livros memorialísticos, representados por autores como Pedro Nava, Alfredo Sirkis, Renato Tapajós e muitos outros. Quanto às mulheres escritoras, são contemporâneas a Zélia as autoras Lygia Fagundes Telles, Rachel de Queiroz, Clarice Lispector e outras que atuaram neste "cenário literário", como Nélida Piñon, Lya Luft, Hilda Hilst e Marina Colasanti.

Evidentemente que Zélia pode ter se inserido no campo literário por certa influência de seu esposo, uma vez que ele era bastante reconhecido por seus pares e fazia parte de uma rede de contatos com editoras consagradas do período, como a José Olympio, a Editora Martins e a Editora Record, esta última bastante relacionada a Zélia e Jorge. Certamente, seria muito mais difícil adentrar o mundo das letras sendo uma mulher anônima, sem nome e sem contatos importantes. No entanto, não se pode atribuir sua estréia tão somente ao fato de ter alguém que apoiou seus projetos, o que configura uma injustiça ao reconhecimento de seu talento e capacidade como escritora.

Deste modo, faz-se necessário considerar outras questões, outros pontos de igual relevância, como o seu talento e experiência, as questões de gênero, as que se referem às mudanças econômicas e, sobretudo, sociais que estavam aparecendo na sociedade de sua época.

Deve-se levar em consideração que a modernização da sociedade brasileira implica uma mudança drástica do cenário cultural. Paralelamente à integração econômica das diversas regiões do país, consolida-se, pela primeira vez, um mercado de bens simbólicos em nível nacional. $O$ advento da indústria cultural coincide com o período da ditadura, esse é o momento em que a televisão transforma-se num veiculo de massa, o cinema consolida-se como atividade financiada pelo Estado, desenvolve-se de maneira ampla a indústria fonográfica, editorial e publicitária².

Além disso, o fator principal que deve ser levado em conta é que Zélia Gattai começou a ser reconhecida desde o início de sua carreira e seus livros foram lançados e editados em outros países, conquistando inúmeros leitores ao longo dos anos, o que demonstra que fora realmente reconhecida pela particularidade de sua obra que é majoritariamente memorialística, resultado de sua dedicação e compromisso com a escrita.

O sucesso de Zélia se deu, como a todo escritor, devido a vários fatores: a influência editorial, o mercado em alta, inclusive para as escritoras, não se restringindo ao mundo masculino e, sobretudo, pelo fato de ter sido aceita por um público leitor interessado em suas obras e na forma como tecia sua narrativa. Para o panorama social de Anarquistas, graças a Deus há também

\footnotetext{
2 ORTIZ, Renato. Revisando o tempo dos militares. In: MOTTA, Rodrigo Patto Sá; AARÃO, Reis Daniel; RIDENTE, Marcelo (Org.). A ditadura que mudou o Brasil: 50 anos do golpe de 1964. Rio de Janeiro: Zahar, 2014, p. 119.
} 
outros fatores que devem ser elencados, tais como o processo de abertura política e a industrialização da produção cultural, fruto do "milagre econômico" ocorrido durante o governo militar. Sobre o período, Reimão pondera que:

[...] a queda nas taxas do analfabetismo, o crescimento do número de universitários e o crescimento do Produto Interno Bruto, informam e esclarecem o crescimento quantitativo do mercado editorial nacional nos anos 70, década em que se ultrapassa a deplorável barreira de um livro por habitante ao ano ${ }^{3}$.

No mesmo ano em que Zélia publica seu primeiro livro Fernando Gabeira lança $O$ que é isso companheiro?t Conforme Reimão, "este livro vendeu cerca de 80 mil exemplares em 1979 e Gabeira reacende com esse texto um filão que se desenvolverá mais na primeira metade dos anos $80^{\prime \prime 5}$.

Em relação ao aumento de publicações literárias no período, bem como ao aumento de leitores e escritoras que adentram ao cânone literário ${ }^{6}$, além dos fatores elencados, outro fator de grande importância foi o processo de emancipação feminina na década de 1970, o que veio a fortalecer a produção de "autoria feminina" na sociedade brasileira. Como aponta-nos Teixeira, "tratase de uma luta, uma busca, que tinha como intuito fazer com que as vozes femininas também fossem ouvidas, tendo em vista que as mulheres sofreram ao longo da história um processo de silenciamento e exclusão"7.

Este aumento do número de publicações por escritoras demonstra uma mudança no campo literário no Brasil, pois as mulheres sempre estiveram em desvantagem em relação aos homens, como pontua-nos Rossini:

\footnotetext{
${ }^{3}$ REIMÃO, Sandra. Mercado editorial brasileiro. São Paulo: ComArte, FAPESP, 1996.

${ }^{4} \mathrm{O}$ escritor Fernando Gabeira, por conta do sucesso com a publicação de seu livro, acabou recebendo no ano de 1980 o prêmio Jabuti na categoria Biografia e/ou Memórias, o que demonstra que o gênero biográfico já estava sendo valorizado e fazia parte do cenário literário neste período. O prêmio foi criado no ano de 1958 pelo presidente da Câmara Brasileira do Livro Edgar Cavalheiro e o secretário Mário da Silva, sendo destinado aos escritores de todas as áreas envolvidas no processo de criação e produção de um livro. Informações disponíveis no sítio eletrônico: <http//premiojabuti.com.br/o-jabuti/historia/> Acesso em: 30 out. 2014.

${ }^{5}$ Ibid., p. 30.

6 "O cânone literário é uma forma institucionalizada que define e determina o que vem a ser a sua literatura representativa, isto é, os textos de referência que recortam a singularidade discursiva e a representacional daquela cultura. Neste sentido, ele é resultado de valorações dentro de um contexto em que muitos fatores entram em jogo, por exemplo, gênero literário prestigiado e estilo predominante numa época, mas cuja base reside no discurso crítico e das instituições que o abrigam." Disponível em: RAMALHO, Christina. Literatura e Feminismo. Propostas teóricas e reflexões criticas. In: SCHMIDT, Rita Therezinha (Org.). Recortes de uma História: a construção de um fazer/saber. Rio de Janeiro: Elo, 1999.

7 TEIXEIRA, Nincia Cecília Ribas Borges. Letras transgressoras na escrita de autoria feminina: Greta Benitz e as palavras em rotação. Vol., 12, 2011, p. 279-297. Disponível em: <pfile///C:/Users/windows\%208/Downloads/8399-26837-1-PB.pdf> Acesso em: 20 out. 2013.
} 
Tradicionalmente, as mulheres foram, nas esferas que abrangem o social, o histórico, o político e o estético, consideradas como inferiores ao sexo masculino. Em decorrência da política do patriarcalismo, a mulher foi silenciada, excluída e vitimada por preconceitos e estereótipos lançados em sua imagem ao longo da história ${ }^{8}$.

Naquele momento, essa desvantagem homem-mulher dava-se devido a uma cultura machista que não fora capaz de conceber que havia, para as mulheres, um espaço além do ambiente doméstico; este espaço não fora negado apenas a elas: os negros e os homossexuais também não tiveram por muito tempo o direito de manifestar seus pensamentos nem um lugar no campo das letras e em outros campos profissionais. Ou seja, antes das décadas de 1970 e 1980 poucas escritoras foram reconhecidas, sendo uma exceção o caso da romancista Rachel de Queiroz "que estreou ainda muito jovem, em 1930, e da poetisa Cecília Meireles, morta em 1964." ${ }^{\prime 9}$

Apesar das dificuldades as escritoras, dentre as quais Zélia Gattai, começaram a aparecer no cenário literário, rompendo de forma gradativa com os preconceitos existentes na sociedade patriarcal e criando mecanismos para poder transitar neste meio, a partir de suas construções narrativas, "desmascarando a naturalização das diferenças hierarquizadas de gênero, consequentemente, problematizando o cânone literário estabelecido"10.

Como coloca-nos Teixeira, dentro deste contexto de problematização do cânone literário é que ocorreu um aumento significativo do número de publicações de mulheres entre as décadas de 1975 e 1985: "[...] essas mulheres buscavam se libertar dos papéis tradicionais, tanto no plano social quanto no literário"11. Ao escreverem seus livros, explicitarem seus pensamentos, expressarem seus sentimentos, medos, criar personagens e histórias, as mulheres iam conquistando o direito a voz, passando a representar uma experiência feminina distanciada da perspectiva hegemônica masculina.

Um dado significativo em relação a essas publicações femininas é que a maioria delas, salvo as exceções ${ }^{12}$, foi lançada por mulheres brancas, pertencentes à elite econômica brasileira, sendo que grande parte teve contato

\footnotetext{
${ }^{8}$ ROSSINI, Tayza Nogueira. Brasiliana - Journal for Brazilian studies. v. 3, n. 1. Jul, 2014, p. 288-312. Disponível em: http://ojs.statsbiblioteket.dk/index.php/bras/article/view/16761/15491 Acesso em: 23 dez. 2014.

${ }^{9}$ CUNHA, Helena Parente. O desafio da fala feminina ao falo falocêntrico. Aspectos da literatura de autoria feminina na ficção e na poesia dos anos 70 e 80 no Brasil. In: RAMALHO, Christina. (Org.). Literatura e feminismo. Propostas teóricas e reflexões teóricas, [s.l.], [s.n.], 1999, p. 151-171.

${ }^{10}$ Ibid., p. 291.

${ }^{11}$ Ibid., p. 286.

${ }^{12}$ A escritora Ana Lins dos Guimarães Peixoto tinha o pseudônimo de Cora Coralina, com o qual lançou o seu primeiro livro Poemas dos becos de Goiás e estórias mais, pela Editora José Olympio no ano de 1965. Cora é um exemplo de mulher que se tornou escritora mesmo tendo pouca instrução e que não fazia parte de uma elite. Igualmente, é o caso da escritora Carolina Maria de Jesus, que escreveu Quarto de despejo: diário de uma favela, lançado em 1960. Tratase de uma mulher pobre, negra e que morava na favela, muito diferente da realidade das outras escritoras que fizeram parte do cânone literá rio deste período.
} 
com a literatura estrangeira ou mesmo morou em outros países, adquirindo experiências e visões de mundo plurais, travando contato com ideais feministas e com diferenças culturais significativas, o que fora de grande importância para a ampliação de seus horizontes intelectuais e para a própria produção de seus trabalhos literários, bem como a percepção de sua própria existência como mulher. Muitas delas eram casadas com homens notáveis, como escritores e políticos também pertencentes a uma elite econômica e intelectual; é o caso de Zélia Gattai.

Este aumento das publicações foi muito significativo do ponto de vista da manifestação da voz da mulher, pois algumas mulheres conseguiram efetivamente expressar seus sentimentos, muito diferente dos séculos anteriores quando, ao se fazê-lo, partia-se do anonimato ou pela via do pseudônimo masculino. Desse modo, "as autobiografias de mulheres dão voz a saberes assujeitados porque as perspectivas e experiências femininas até recentemente foram excluídas da história e da literatura"13.

Há neste sentido um reentendimento do poder do homem no campo literário, mas também em outros setores profissionais, que teve como consequência a visibilidade da mulher no âmbito social. Teixeira coloca-nos que o resgaste do termo "feminino" de um

contexto semântico eivado de preconceitos e estereótipos equivale a reescrevê-lo numa prática libertadora que tem como objetivo tornar visível o que foi silenciado e colocado em plano associado ao rótulo de expressão menor ${ }^{14}$.

A escrita de Zélia, tanto a autobiografia quanto a de romance, contemplou também 0 assunto em questão, discutindo as questões relacionadas ao "mundo feminino", como o casamento, o sexo, o divórcio, a educação dos filhos, a traição, a virgindade, o machismo, os valores tradicionais e outros assuntos que teve interesse em explicitar. Trata-se de questões sobre a sua experiência como mulher no mundo, no seu dia a dia, em suas redes de relações com a sociedade e com os poderes estabelecidos. Isso também foi feito por outras escritoras, não somente na construção de autobiografias, mas de outros gêneros literários, como os romances e os contos.

Há nas obras de Zélia um engajamento como mulher, relatando suas memórias, preferências literárias, militando politicamente, denunciando abusos de certos sistemas de poder que presenciou ou mesmo que ouviu falar. Também narrou a sua trajetória, desde as lembranças de sua infância e fase adulta. Neste sentido, há em sua literatura, como em tantas outras de sua época, a vontade da mulher em exteriorizar todos esses sentimentos, que por muito tempo foram guardados ou mesmo silenciados.

13 RAGO, Margareth. A aventura de contar-se: feminismos, escrita de si e invenções da subjetividade. Campinas. São Paulo: Editora Unicamp, 2013, p. 54.

${ }^{14}$ Ibid., p. 284. 
Apesar de a autora ter publicado Anarquistas, graças a Deus em plena ditadura militar, os temas que narrou tratava sobre outros assuntos, como a imigração italiana no Brasil, principalmente no que se refere à viagem de seus antepassados. Tratou de falar sobre a violência que ocorria durante o Estado Novo na qual o seu pai também fora uma das vítimas, por conta de ter sido ele considerado homem perigoso, pois possuía uma espingarda de caça e um material bastante "subversivo" em sua casa, como os livros de Émile Zola e Pietro Góri e mais alguns artigos com conteúdos políticos, "provas" suficientes para incriminá-lo na perspectiva dos militares do regime.

Outros assuntos também foram abordados neste primeiro lançamento, como a modernização da cidade de São Paulo, relatando as histórias dos habitantes do bairro do Bixiga, narrando também os costumes das italianas, sobre os espaços de lazer que existiam no momento, além de outras temáticas. Tal tema foi novamente narrado em outro livro publicado pela autora intitulado Città di Roma (2000) onde relata o que ocasionou a morte de seu pai, pelo qual nutria grande afeto: "Acometido de febre tifoide, o organismo de papai não resistiu. Morreu aos cinquenta e quatro anos, vítima das atrocidades da polícia do Estado Novo"15.

Com a leitura de suas obras podemos perceber que, desde o primeiro livro, Zélia mostrou-se bastante preocupada com a construção de sua memória individual e também de memórias "alheias" como as de seus familiares, dos seus amigos e de outras pessoas com que conviveu, seja na infância ou mesmo em outros momentos de sua vida. Nos livros seguintes, a construção de memórias tornou-se uma prática recorrente, os temas por vezes variavam, mas a prática memorialista permanecia em cada nova publicação.

Se em Anarquistas, graças a Deus e em Città di Roma o foco foi debruçar-se a narrar as histórias de sua família, nas publicações seguintes, como Um chapéu para viagem (1982), Senhora dona do baile (1984) e Jardim de inverno (1988), ela se concentra em contar sobre o tempo em que vivenciou o exílio na Europa com seu esposo.

Tal constatação leva-nos a várias indagações: Quais as particularidades da escritura da autora? Por que a autora escreve? Existe algum intuito com a sua escrita memorialista? Se existe, qual o motivo que a levou a produzir suas obras? Como se apropriou do passado para construir as suas memórias? Estas e outras questões serão discutidas no tópico seguinte.

\section{A memória e o passado em Zélia Gattai}

Foi no final da década de 1970 que Zélia publicou seus livros, debruçando-se a narrar sobre a sua trajetória de vida, informando sobre a sua própria educação/instrução, a sua relação com a família, a sua rede de amizades e sobre outras questões. Desta forma, criou uma memória de si, olhando para o passado, tentando recuperar as lembranças dos momentos

${ }^{15}$ GATTAI, Zélia. Città di Roma. 7a ed., Rio de Janeiro: Record, 2002, p. 168. 
vividos. Neste sentido, pôde contar as suas experiências, exteriorizar seus sentimentos, relatar seus medos e visões de mundo.

Destas particularidades, pode-se dizer que grande parte dos textos literários da escritora preocupa-se em enfatizar sua individualidade, pelas histórias de sua própria vida. Neste sentido, entendemos como Philippe Lejeune que as obras de Zélia Gattai são autobiográficas, pois trata-se "de um relato retrospectivo em prosa que faz de sua própria existência, colocando ênfase em sua vida individual e, em particular, na história de sua personalidade ${ }^{\prime 16}$. No entanto, apesar de ter um aspecto autobiográfico, há também um caráter biográfico por apresentar em seus textos uma clara construção de memórias de "terceiros" onde contempla as histórias de alguns indivíduos de seu círculo familiar, como a de seu esposo, de alguns amigos, de consagrados escritores, poetas e poetisas, de pessoas comuns, dentre outras, pois como nos mostra Arfuch "toda biografia ou relato da experiência é, um ponto, coletivo, expressão de uma época, de um grupo, de uma geração, de uma classe, de uma narrativa comum de identidade ${ }^{17}$.

Levando em consideração a existência de tais características, podemos afirmar que em seus textos há o intuito pessoal de se posicionar e evocar o seu próprio passado, permitindo-se rememorá-lo e, a partir de seu tempo presente, dotá-lo de novos significados, assim como conceder voz a certas pessoas e acontecimentos que julga importante, sendo motivada por questões de ordem emocional, política ou mesmo social. Deste modo, realiza também a construção biográfica, a narração de histórias alheias, reproduzindo, a partir de sua escritura, como assinala François Dosse, "um vivido real passado segundo as regras da mímeses e o seu pólo imaginativo"18.

Em sua narrativa, além do recurso das próprias lembranças, Zélia recorre à sua imaginação, rica de detalhes, de certas descrições que julga pertinente e à sua criatividade como escritora, organizando os acontecimentos que pretende contar ao leitor, criando desta maneira a sua história de vida e a de outras pessoas que relata de modo coerente, dando a impressão de que tais eventos foram vivenciados exatamente como foram narrados, sendo uma prática comum nestes tipos de relatos de vida, pois, como bem informa Dosse, "o biografo [...] se encontra o mais perto possível do autentico, a ponto de alimentar às vezes a ilusão de restituir inteiramente uma vida"19.

Se há a construção autobiográfica e também a biográfica é neste sentido que a sua obra torna-se uma literatura híbrida, porque é composta por gêneros literários distintos. Além disso, a construção de memórias internas torna a sua obra uma literatura essencialmente ficcional, pois não há como garantir, ou

\footnotetext{
${ }^{16}$ LEJEUNE, Philippe. O pacto autobiográfico: de Rousseau à internet. Tradução de Jovita Maria Gerheim Noronha e Maria Inês Coimbra Guedes. Belo Horizonte: Editora da UFMG, 2008, p. 14.

${ }^{17}$ ARFUCH, Leonor. O espaço biográfico. Dilemas da subjetividade contemporânea. Tradução de Paloma Vidal. Rio de Janeiro: Editora da Universidade do Estado do Rio de Janeiro, 2010, p. 100.

${ }^{18}$ DOSSE, François. O desafio biográfico: escrever uma vida. Tradução de Gilson César Cardoso de Souza. São Paulo: Editora da Universidade de São Paulo, 2009, p. 55.

${ }^{19}$ Ibid., p. 59.
} 
comprovar a autenticidade de sua narrativa. De acordo com Glaucy Amaral, "relembrar o passado não possibilita o recuperar da ação no tempo, pois a cada lembrança é revivida pela memória, o passado remodelado passa a fazer parte do presente atuante ${ }^{\prime 20}$. É neste sentido que entendemos que seus textos são autobiográficos e também memorialísticos, pois contemplam a memória individual e a memória coletiva. Sua autobiografia situa-se, deste modo, na fronteira entre o relato narrado como verídico, inserido em um campo ficcional, e o da construção literária.

O que nos interessa a partir de tais constatações referentes a escritura de Zélia, é entender o motivo pelo qual escreve seus textos e como utiliza as lembranças do passado para atingir seus fins. Evidentemente que não escreve sem um objetivo concreto; neste sentido, entendemos que há uma intencionalidade, ou melhor, há várias intenções que a levam a publicar suas autobiografias. Para tanto, faz uso de "ferramentas" que lhe permite construir memórias a partir de suas lembranças pessoais e de algumas que toma "emprestado" de seus próprios antepassados.

Em suas narrativas evoca as lembranças do passado, faz uso de sua imaginação, reconstruindo, deste modo, suas experiências e as de outras pessoas, ora querendo registrá-las, documentá-las, ora para "denunciar" certos eventos que vivenciou, ora para se colocar como porta voz de vozes silenciadas. Trata-se, portanto, de práticas comuns em todos os seus livros com caráter memorialístico.

As obras Anarquistas, graças a Deus e Città di Roma, apesar de serem livros publicados em momentos diferentes, revelam aproximações temáticas e interesses semelhantes, especialmente porque que tratam da imigração italiana para o Brasil no início do século XX. Por isso, seus livros não são divididos em capítulos; há uma divisão temática com o intuito de mostrar ao leitor o assunto que será abordado em seus textos, tal como fez em Anarquistas, graças a Deus, nas seções Começo de viagem, Serviço de imigração e saúde e Fim da colônia Cecília ${ }^{21}$, escritos geralmente em textos curtos. Em Città di Roma e nos demais livros que escreveu, ela repete a mesma forma de organizar suas ideias a partir de tais divisões, utilizando títulos muito parecidos com os de Anarquistas, graças a Deus, Posto de imigração sanitária, $A$ viagem e $A$ viagem dos Dacol $^{22}$, dentre outros.

Deste modo, Zélia Gattai apropria-se das experiências, sentimentos e recordações do passado de seus antepassados, criando uma narrativa a partir de dados históricos sobre o período, informando eventos, como sua viagem até - Brasil, suas expectativas, os seus desafios e a adaptação em terra desconhecida. O excerto que segue, extraído de Città di Roma, revela-nos estes aspectos de sua escritura:

\footnotetext{
${ }^{20}$ AMARAL, Glaucy Cristina. A narração memorialística em A casa do Rio Vermelho, de Zélia Gattai: uma meta memória. 2010. 85f. Dissertação de mestrado. Programa de estudos pósgraduados em literatura e crítica literária. Pontifícia Universidade Católica. São Paulo. 2010, p. 16.

${ }^{21}$ GATTAI, Zélia. Op. cit., p. 132, 134 e 136.

${ }^{22}$ Ibid., p. 15, 13 e 25.
} 
A travessia de Gênova para o porto de Santos foi longa e penosa, contava tio Guerrando. Não posso esquecer. Amontoados e tristes como gado a caminho do matadouro, os imigrantes enjoavam nos porões escuros e quentes, ao lado das caldeiras do navio, um verdadeiro inferno. A gente ia aguentando sem reclamar. Todo mundo tinha um medo terrível de ficar doente e acabar morrendo em alto-mar. Vocês sabiam não é? Explicava titio, nos navios daquela época não havia frigorífico para conservar cadáveres, e os corpos de quem morresse durante a travessia eram jogados no mar $^{23}$.

Zélia, nos dois livros, Anarquistas graças a Deus e Città di Roma, relata os depoimentos de seus familiares. Dessa forma, reconstrói algumas historias que julga mais importante. A escritora parece reproduzir o que realmente ocorreu no passado, a partir das informações que possui com o apoio de sua imaginação. Como bem disse Dosse, "o biografo [...] se encontra o mais perto possível do autentico, a ponto de alimentar às vezes a ilusão de restituir inteiramente uma vida"24. Ou seja, quem escreve sobre uma vida por meio de relatos pessoais preocupa-se em dizer a verdade sobre os "personagens" biografados. Além disso, o leitor de um texto (auto)biográfico pretende encontrar as verdades sobre essas trajetória(s). Em outras palavras, "publicar uma biografia, anuncia-la como tal e não como romance é prometer fatos verídicos $[\ldots]^{\prime 25}$. No entanto, as lembranças, sejam elas, individuais ou coletivas não são plenamente confiáveis, sendo transbordada de lacunas, passiveis, neste sentido, de erros e falhas. Deste modo, com ou sem a intencionalidade do biografo, é comum nas escritas de si ocorrer desvios e algumas imprecisões em relação aos fatos históricos narrador.

Por tratar-se de um conjunto de textos autobiográficos, devemos considerar que há um intuito por parte da autora em relatar as historias de vida como sendo verdadeiras e fiéis aos acontecimentos do passado. No entanto, as lembranças individuais ou partilhadas com o seu grupo familiar são insuficientes para dar conta de dizer o que realmente ocorreu em determinado espaço ou tempo.

O titulo Città di Roma, escolhido pela autora, se refere ao navio que os seus antepassados embarcaram em Gênova rumo ao Brasil. Segundo a Zélia Gattai, isso teria ocorrido em 1890:

O grupo de idealistas embarcou no navio "Città di Roma" em fevereiro de 1890; o regime imperial no Brasil havia sido derrubado a 15 de novembro de 1889 . D, Pedro II fora deposto e desterrado, a República proclamada. Os fundadores da "Colônia Socialista Experimental" não podiam mais contar com a ajuda e o apoio prometido pelo Imperador. Contariam apenas

\footnotetext{
${ }^{23}$ Ibid., p. 13-14.

24 Ibid., p. 59.

${ }^{25}$ Ibid., p. 59.
} 
com seus próprios esforços, com a vontade de vencer, mas nada os faria recuar. No porão do "Città di Roma", junto às caldeiras, viram-se amontoados os pioneiros que, em breve, estariam integrando uma comunidade de princípios puros: a "Colônia Cecília". Iam cheios de esperanças, suportariam corajosamente as condições infames da viagem ${ }^{26}$.

Esta afirmação traz-nos duas imprecisões observadas por Isabele Felici em seu artigo intitulado: $A$ verdadeira História da Colônia Cecília de Giovanni Ross $^{27}$. A primeira, em relação ao navio que os imigrantes viajaram, que ao contrario que Zélia afirmara, não teria sido no Città di Roma, mas no navio Vittoria. A segunda falha, diz respeito à data do embarque, que a partir das pesquisas de Felici, teria ocorrido no ano de 1891 como nos mostra no trecho a seguir:

Em fevereiro vários grupos embarcam em Gênova em direção à Palmeira. Seis famílias originárias de Litorno partem no dia 03 de fevereiro de 1891, no navio Vittoria. Entre eles está Eugenio Lemmi. Um segundo grupo, mais numeroso, dezesseis famílias e alguns solteiros, originários de Cecina, Gênova, Turim, Milão e Brescia, embarca no dia 14 de fevereiro de 1891. No dia 10 de março, é a vez de treze famílias e sete homens solteiros de Florença, Poggibonsi, La Spezia e Milão. Francesco Argia Gattai, os avós de Zélia Gattai, e suas crianças, fazem parte desse grupo que viajou no dia 10 de março de 1891, e portanto, não partiram a bordo do Città di Roma, contrariamente ao que ela diz em seu livro de memorias, Anarquistas graças a Deus s. Essa observação não diminui em nada o valor do testemunho de Zélia Gattai e a carga emotiva que contém o relato, particularmente comovente, que ela faz da viagem de seus avós: a última criança da família Gattai, um recém-nascido, morre de fome na chegada ao porto de Santos ${ }^{28}$.

Como defendido por Felici, os dados imprecisos relatados por Zélia, não exclui o mérito de seus relatos, mas nos indica lacunas que são muito presentes em suas obras ou em qualquer outro trabalho autobiográfico. O foco nestes dois livros, além da ênfase na viagem de travessia Itália-Brasil, foi na incorporação de novos temas, como o da modernização da cidade de São Paulo, o dos espaços de lazer que haviam naquele momento, avivando questões como religião, gênero, literatura, política, valores morais, entre outros. Assim, a escritora posicionava-se ora como narradora, ora como personagem de sua própria história.

Zélia é uma escritora que não pretende, a partir de sua literatura, apenas informar sobre a trajetória de vida de seus pais e avós, mas registrar tais acontecimentos, arquivando histórias de vidas que ela julga importantes, a

\footnotetext{
${ }^{26}$ GATTAI, Zélia. Anarquistas graças a Deus. Rio de Janeiro: Record, 1979.

27 FELICI, Isabeli. A verdadeira historia da Colônia Cecilia de Giovanni Rossi. Revista Cadernos AEL. Campinas, v. 5, 1998, p. 9-67.

${ }^{28}$ Ibid., p. 18.
} 
ponto de não querer que caiam no esquecimento. Podemos perceber que as escolhas que ela fez determinou o sentido que pretendia dar à sua própria vida, como pontua Philippe Artières:

\begin{abstract}
Numa autobiografia, a prática mais acabada desse arquivamento, não só escolhemos alguns acontecimentos, como ordenamos numa narrativa; a escolha e a classificação dos acontecimentos determinam o sentido que desejamos dar às nossas vidas ${ }^{29}$.
\end{abstract}

Mas, além disso, há outra intenção com a sua escrita, que é uma preocupação com si própria no sentido de se construir como sujeito em sua literatura. Zélia também faz de sua escritura memorialística uma "ferramenta de resistência", a partir do momento em que relata suas dores, seus ressentimentos, as vivências traumáticas, bem como as injustiças que presenciou ou mesmo de que ouviu falar. Deste modo, tece a sua narrativa, registra e denuncia certos acontecimentos; é a forma de posicionar-se, de exteriorizar seus sentimentos, emoções, seus valores como mulher, como militante e como sujeito histórico. Foi o que procurou fazer relatando, por exemplo, a prisão de seu pai Ernesto Gattai pelo Estado Novo:

$\mathrm{Na}$ portaria da delegacia, deixamos roupas para substituir as que papai usava desde a madrugada de sua prisão, roupas já quase podres, fedendo de quase não se aguentar, ninho de muquiranas... O rapaz que recebeu as roupas e uma sacola com escova de dentes, pasta e sabonete, que levamos, não deu certeza se elas seriam entregues. Não foram entregues ${ }^{30}$.

Do excerto citado fica claro que a autora permitiu-se narrar, registrar e denunciar um evento triste sobre a prisão de seu pai, acontecimento extremamente marcante em sua vida, pois, segundo ela, foi o fator responsável que deixou a saúde de seu Ernesto debilitada, vindo a falecer posteriormente em decorrência da violência física e psíquica sofrida. Pode-se dizer que a partir de seus livros é que Zélia pôde se posicionar como testemunha de tais eventos em sua vida. Como assinala Artières, "este é um traço comum dessas práticas: arquivar a própria vida é querer testemunhar"31.

Para além de Anarquistas, graças a Deus e Città di Roma, nas obras Um chapéu para viagem (1982), Senhora dona do baile (1984) e Jardim de inverno (1988), também faz de sua narrativa um espaço de construção de memórias, desabafo individual e coletivo, posicionando-se como testemunha dos eventos vividos e outros que não presenciou, mas que tomou para si o dever de

\footnotetext{
${ }^{29}$ ARTIÈRES, Philippe. Arquivar a própria vida. Estudos históricos. v. 8, n. 21 . Rio de Janeiro: FGV, 1998, p. 09-34.

${ }^{30}$ GATTAI, 2000, p. 167.

${ }^{31}$ Ibid., p. 20.
} 
divulgá-los e documenta-los. Interessa ressaltar que, apesar de continuar a ter uma postura memorialística nestes livros, as temáticas que escolheu para narrar não contemplam, com a mesma intensidade, a história de sua família e os relatos de seus antepassados; neste caso, concentra-se em narrar o exílio (1948-1952) partilhado com Jorge Amado. Neste sentido, a sua narração ocupou-se de construir a sua memória e a de seu esposo, juntamente com os intelectuais de esquerda, escritores, filósofos e filósofas, dentre outras pessoas de seu círculo de convivência.

Nestas obras, percebe-se que há uma Zélia escritora mais engajada do ponto de vista político, pois se coloca a tratar de assuntos relacionados à guerra fria, ao holocausto, ao stalinismo, ao socialismo, ao macarthismo, as injustiças políticas, aos conflitos ideológicos, relatando os congressos e reuniões de que seu esposo participou, os problemas sociais que presenciou nos países que visitou, como é o caso da China, e de outros mais a que se debruçou a narrar. Sobre este episódio, são suas as palavras:

Tudo se sabia da China, no Brasil, coisa pública e notória, era que a perseguição política recrudescera, acentuara-se 0 retrocesso democrático desde que o governo de Mao Tse-Tung recusara-se a aceitar e a apoiar as revelações de Nikita Kruschev no XX Congresso do Partido Soviético, após a morte de Stalin. Ao revelar os crimes do stalinismo, Kruschev propunha uma nova política baseada na denúncia do culto à personalidade e das violações, tantas e tão monstruosas, da legalidade socialista, da democracia. $O$ governo chinês repudiou, preferiu ficar com a moral stalinista; o culto a Mao não tinha limites ${ }^{32}$.

As três obras citadas anteriormente complementam-se no sentido de que Zélia começa a narrar o seu exílio em Um chapéu para viagem, publicado em 1982 e nas obras seguintes continuará a tratar desta temática, finalizando o assunto em Jardim de inverno, lançado em 1988. Neste livro, faz um balanço do que vivenciou em país distante, contando a sua experiência, deixando claro ao leitor que depois de tais vivências já não era mais a mesma, ou seja, trata-se de outra mulher, com uma nova identidade criada a partir das novas oportunidades que teve, ampliando seus horizontes como mulher $e$ posteriormente como escritora e memorialista. Amadurecida, com outra concepção de mundo, afirmou:

Nesse porto de Gênova eu desembarcara em 1948, com uma criança nos braços, no peito muito amor e muita coragem. Houve quem me tachasse de irresponsável, ao ver-me sair mundo afora ao encontro de meu companheiro com um filho pequeno. Agora, em 1952, neste mesmo porto de Gênova, ao partir de volta para casa, eu já não era a moça ingênua que lá aportara, cheia de ilusões, sectária, limitada, com uma visão idealista do mundo. Vivera um tempo longo de saudade e de

${ }^{32}$ GATTAI, Zélia. Jardim de inverno. 8a ed. Rio de Janeiro: Record, 2001, p. 193. 
nostalgia, um tempo dramático de guerra-fria, macarthismo, stalisnismo, injustiças, desconfianças, acusações e delações: o medo desenfreado condicionando a existência das pessoas. Passara a conhecer melhor a vida. Não fora fácil, mas a gente vai aprendendo sem parar, apanhando para aprender: eu apanhei bastante ${ }^{33}$.

Não nos é difícil assumir que Zélia pode construir-se como mulher a partir de todas essas vivências no exílio. Por meio de tais acontecimentos pode observar, experimentar novas realidades e presenciar eventos tristes, situações de injustiça entre certos grupos e até mesmo rever certos princípios e valores políticos que nutriu em sua vida por muitos anos. Deste modo, distante de seu país pode reconstruir-se como mulher, como sujeito histórico, deixando de lado alguns referenciais ideológicos, rompendo com certas ilusões políticas como o socialismo, por exemplo, pois havia percebido que o poder muitas vezes era equivocado, injusto, violento e autoritário, assim como o stalinismo e o maoísmo, que se debruçou a relatar em suas histórias nas páginas de seus livros.

Cabe destacar também que Zélia mostrou em suas obras a sua indignação e desilusão com o "sonho socialista", mostrando com sua narrativa as intervenções que faziam antes de publicarem os textos de seu esposo nos países socialistas que sofriam cortes em certas palavras e frases além de excertos que, segundo admite a escritora, "ainda sim, sobrava o que ler, um sopro de vida verdadeiro, mesmo podados, representavam uma abertura" ${ }^{\prime 34}$. Além de tais intervenções, havia outros eventos insertos no socialismo e praticados por alguns dos seus membros que presenciou ou ouviu falar, como eventuais condenações de pessoas inocentes, enforcamentos, entre outras atitudes que restringiam a liberdade de muitas pessoas. Neste sentido, Zélia Gattai começa a questionar o socialismo e, de maneira bastante crítica, afirma:

O socialismo que eu aprendera a respeitar, desde criança, com meu pai, era outro, muito outro, completamente diferente... Meu pai me ensinara que sem liberdade o homem não pode viver. Não há dúvida, os princípios do socialismo significavam um avanço da sociedade. Os homens que aplicavam é que, muitas vezes, não estavam à altura. Coisa tão simples de analisar, tão fácil! Não era preciso possuir conhecimentos teóricos do marxismo, bastava ter cabeça para pensar, olhos para ver e coração para sentir para se chegar a conclusão de que ambição pessoal, a sede do poder, era responsável por tudo de ruim que acontecia. A ambição do poder transforma, corrompe o indivíduo. Há homens que para chegar ao poder fazem qualquer negócio... No poder, passam a ver inimigos em

\footnotetext{
${ }^{33}$ Ibid., p. 224.

${ }^{34}$ Ibid., p. 47.
} 
seu redor, querendo tomar-Ihes a frente, querendo fazer-Ihes sombra, querendo tirar-lhes as vantagens... Para não perder 0 mando, recorrem a dogmatismo, valem-se de todo e qualquer processo para liquidar o concorrente: tornam-se inflexíveis, não admitem queixas, muito menos críticas, tolhem as liberdades, utilizam as polícias e os tribunais, forjam crimes para liquidar os que os incomodam ${ }^{35}$.

O que se compreende a partir desta afirmação é que a escritora conseguiu por meio de sua literatura posicionar-se, mostrando que o poder com ambição leva a regimes violentos e, consequentemente, a atitudes desumanas, por parte de seus membros, o que fez com que ela revesse o socialismo, não o vendo mais como um ideal a ser alcançado e construísse as suas memórias com o intuito de arquivar tais vivências.

\section{Palavras finais... Um refletir em Zélia}

Em todas as suas obras memorialísticas podemos observar que Zélia as construiu com o intuito de deixar tais experiências para a posteridade, promovendo um legado no sentido de querer mostrar aos seus leitores que qualquer regime político que não tenha como propósito o bem comum não poderá ter um poder justo e humano; ao contrário, a autora admite que são estes geralmente os grandes responsáveis por inúmeras atrocidades contra as pessoas que se posicionam contra os seus propósitos. Além disso, ela tinha muitos motivos para querer exteriorizar seus pensamentos, pois fora uma mulher que presenciou a prisão do próprio pai e o exílio do esposo.

Pode-se dizer que objetivou registrar e documentar as histórias dos seus antepassados a partir de seus referenciais ideológicos, sua luta pela sobrevivência na viagem da Itália ao Brasil e a adaptação ao país desconhecido que, com o passar do tempo, foi se tornando aconchegante e se transformando em um verdadeiro lar.

Em suma, a memorialista Zélia Gattai conseguiu, por meio de sua escrita, o que sempre almejou: dar voz a si própria e a outras pessoas que não puderam se posicionar diante do que haviam sofrido. Neste sentido, a escritora fez de sua literatura um instrumento político; não era adepta de partidos, no entanto nutria grandes sonhos, muitas experiências e uma opinião firme sobre as questões relacionadas ao socialismo e a outras temáticas com as quais pode posicionar-se, registrar, documentar e deixar seu legado a partir da tessitura de sua narrativa, "graças a Deus".

${ }^{35}$ Ibid., p. 139. 


\section{Sobre a autora}

Kassiana Braga é graduada em História pela Faculdade de Ciências e Letras da Universidade Estadual Paulista "Júlio de Mesquita Filho" (UNESP/Assis-SP) e mestranda no Programa de Pós-Graduação em História dessa mesma universidade, onde desenvolve a pesquisa $A$ senhora dona da memória: autobiografia e memorialismo em obras de Zélia Gattai, fomentada pelo Conselho Nacional de Desenvolvimento Científico e Tecnológico (CNPQ). E-mail: kassianahistoriabraga@gmail.com. O texto apresentado é resultado parcial do primeiro capítulo de sua dissertação de mestrado.

Artigo recebido em 28 de fevereiro de 2015.

Aprovado em 15 de outubro de 2015. 